\title{
The Esoteric Milieu in Finland Today
}

\begin{abstract}
A $s$ in the other Scandinavian countries, so in Finland an exceptionally high percentage of the population belongs to a religious community. Today, about 82 per cent of Finns are members of the Evangelical Lutheran Church. However, the picture of the Finnish religious and spiritual landscape is more complex than it may at first appear.

The project 'Religions in Finland' was started in 2003. The project is a joint-effort of the Church Research Institute and the Research Network for the Study of New Religious Movements. The aim is to create an electronic database for describing, mapping and analysing religious associations and communities in Finland (active ones and also those that no longer exist).

In August 2007 there were 777 communities and organizations listed in the database. They are classified into ten categories representing religious traditions according to their historical and cultural background. There are 29 organizations classified under the category Western esotericism. In this article I will present a general overview of the major and recently founded esoteric groups in Finland. Most of these groups are registered associations (the abbreviation $r y$ stands for 'registered association').*

Several statistical and sociological surveys of religiosity in modern Finland have been carried out. They revealed at least the following aspects that are typical in Finnish religiosity (and these aspects apply to many other West European countries too).

Firstly, religion has become an increasingly private matter for people. Secondly, people's religious views and practices are not determined solely by membership of a religious community. Thirdly, religious views
\end{abstract}

* The figures indicate the more or less official number of members in each group. Besides them, there are people in most groups who are involved in the activities of the groups even though they are not actual members. The number of members is estimated by the communities themselves (in 2007). 
and practices are often eclectic. They can be influenced by many new and old traditions from various forms of Eastern meditation and yoga practice to New Age healing practices and spiritualism, for example.

It often said that the religious movements providing an alternative to the Evangelical Lutheran Church have landed in Finland in two phases. The first one was from the late twentieth century onward. The second one started in the early 1970s, when many yoga and meditation traditions were introduced into Finland. The countercultural ideology was also linked with experimental alternative spiritual practices. But after this second phase also, dozens of new religious movements have arrived in Finland (Ketola 2003: 57-62, 81-5). Most groups and organizations have not officially registered as religious communities, despite having at least a religiously oriented background.

\section{The Theosophical Society (Teosofinen seura ry)}

It is fair to say that modern occultism came to Finland mainly through the Theosophical movement. The Finnish Theosophical Society was founded in 1907 (re-founded in 1933). There had also been some theosophical activity before that. One of the founding members of the society was Mr Pekka Ervast (1875-1934). He has been without doubt one of the most important persons within the Finnish esoteric movement.

Despite not ever having more than a few thousand members, the Theosophical Society has had a significant influence and impact. The Theosophical Society introduced non-Christian religious ideas and concepts to a wider public. The Society's role in the construction of an alternative religious culture cannot be underestimated in Finland, either. Today there are about 450 members in the Theosophical Society (www. uskonnot.fi-Teosofinen seura ry).

A prominent member of the International Theosophical Society, Charles Leadbeater founded the Liberal Catholic Church in 1916. Already in 1919 there was a study group in the Helsinki area that anticipated the birth of the Liberal Catholic Church in Finland. Then, in 1929, Vapaa katolinen kirkko Suomessa (The Liberal Catholic Church of Finland) was registered as a religious community. Today it has about $150 \mathrm{mem}-$ bers. From the very beginning, the Theosophical influence has been strong and many members also have affiliations to theosophy today (www.uskonnot.fi-Suomen vapaa katolinen kirkko). 


\section{Christosophia (Kristosofia)}

A purely Finnish theosophical offshoot is the so-called Christosophia (Kristosofia, Wisdom of Christ). The movement has its origins in the spiritual experiences of Mr J. R. Hannula (1873-1956). He was an active theosophist and a great admirer of Mr Ervast.

He started proclaiming that Ervast was a great spiritual teacher equal to the Buddha and Christ. The society especially emphasizes the ethical principles that Ervast formulated and which were based on the Sermon on the Mount. The Finnish Rosicrucian Society prohibited Hannula from continuing his teachings about Ervast. In 1940, Hannula and another theosophist founded a society to spread their own version of theosophy. The society was registered in 1966 by the name Kristosofinen kirjallisuusseura ry (The Christosophical Literature Association). It organizes public lectures and also distributes material about Christosophia. Today the society has about 80 members. The group called Ihmisyyden tunnustajat (Confessors of Humanity) was founded in 1979 to promote the Christosophical and Rosicrucian (Ervast) ideas and lifestyle. Today they comprise three communities in which altogether 45 persons are living (www.uskonnot.fi-Kristosofinen kirjallisuusseura ry).

Another theosophical group is Alice A. Bailey -seura ry (The Alice A. Bailey Association), founded in 2005. The society has about 20 members. It has been involved actively in the project of translating Bailey's books into Finnish (www.uskonnot.fi-Alice A. Bailey seura ry).

\section{Anthroposophy, Christian Community, Parapsychology, Spiritualism, Via Society, and the Summit Lighthouse}

The Theosophical Society invited Rudolf Steiner to give several lectures in Helsinki. Steiner visited in Finland in 1912-13 and some Finnish people joined the newly founded Anthroposophical Society in 1913. In the same year the first study group was formed in the Helsinki area. During the 1930s there arose some criticism and negative attitudes towards Anthroposophy within the Evangelical Lutheran Church.

Suomen antroposofinen seura (The Anthroposophical Society of Finland) was founded in 1923. Due to the language conflict between Finnish and Swedish, Finnish-speaking people wanted to have their own branch of the society. This was founded in 1924. Nowadays this organization is known by the name Suomen antroposofinen liitto ry (The Anthroposophical League of Finland). During the 1970s the anthroposophical 
movement was more active and visible than before. New local groups were founded in five big towns. A very important phase was in 1980, when the Snellman-korkeakoulu (Snellman College, named after a significant Finnish nineteenth-century politician and philosopher) saw the light. It is a private college that offers seminars, courses and lectures in humanist studies, psychology and Anthroposophy.

Today the Anthroposophical movement has about 800 members. Within the league, there is also a Free School of Spiritual Science. This branch consists of groups that study the esoteric teachings of Steiner under the group leader. Only a minority of people who put their children in the Walldorff School (Steiner schools) are members of the Anthroposophical League of Finland (www.uskonnot.fi-Suomen Antroposofinen liitto).

The Christian Community is the ecclesiastical body of Anthroposophy representing a form of esoteric Christianity that derives from the teachings of Steiner. The Christian Community in Finland was founded in the late 1960s. It has about 80 members, but the participants in their services number a few hundreds. The society was registered as a religious community in 1969 (www.uskonnot.fi-Kristiyhteisö Suomessa).

Parapsychological research arrived in Finland at the turn of the twentieth century. It came along with theosophy and spiritualism and was linked with fin-de-siècle occultism. In Finland the Parapsychological Research Association (Swedish-speaking) was founded in 1907. In its early days there were also some academics who had an interest in the experimental studies of spiritualist séances. The Finnish-speaking association was founded in 1938. In post-war Finland spiritualism and parapsychology gained more popularity. However, parapsychology failed to get the status of an academic discipline and it remained a deviant science. It can be clearly seen that since the 1960s the Parapsychological Research Association has become part of popular occultism and alternative spirituality and has started appealing to a wider audience, leaving the academic community behind. Today its main task is to organize public lectures (www.uskonnot.fi-Parapsykologinen tutkimusseura ry).

Spiritualism came to Finland along with parapsychology and the first spiritualist societies were founded in the early twentieth century. Suomen spiritualistinen seura ry (The Spiritualist Association of Finland) was founded in 1946. It has about 1,500 members today. Paranormal themes and also ideas of esotericism became more popular during the early 1970s. The magazine Ultra focussing on the paranormal has been very influential in the field of alternative spirituality since 1974. Despite having its main focus on the theme of UFOs and parapsychology it has 
also often included topics of alternative spirituality and esotericism (Suomen ufotutkijat ry).

Via ry (The Via Association) originates from the personal experiences of two Finnish ladies with a background in theosophy and the Finnish Rosicrucianism. They formulated their own system of the Raja Yoga and positive thinking and started to promote a correspondence course in 1955. Their teaching also shows influences from the Western esoteric tradition. The Via Association was founded in 1977 and today has its own study centre, which offers study programmes focussed on various spiritual traditions and also some psychological subjects. It has been estimated that since the founding of the correspondence course, about 4,000 people have participated in the Raja Yoga correspondence courses. At the moment there are about 250 students involved in that course (www.uskonnot.fi-Via ry).

The Summit Lighthouse (better known internationally by the name the Church Universal \& Triumphant) started its activities in Finland in 1976. Helsingin Summit Lighthouse ry (The Helsinki Summit Lighthouse) organizes services in the Helsinki area. There is also a society called Nuoret mystikot ry (The Young Mystics) that is based on the beliefs and teachings of the Church (www.uskonnot.fi-Helsingin Summit Lighthouse ry, Nuoret mystikot ry).

\section{Rosicrucian Groups}

There are two distinct modern Rosicrucian traditions in Finland. The first tradition consists of the Finnish branches of the international Rosicrucian orders. The second tradition is particular to Finland. This tradition has its origins in a schism within the Finnish Theosophical Society, and it is totally separate from the international orders.

The Antiquus Mysticus Ordo Rosae Crucis or AMORC spread to Scandinavia in the 1920s. The Finnish AMORC was extracted from the Scandinavian Grand Lodge in 1998 and initiated an independent administrative unit Ruusuristin Veljeskunta AMORC-Suomi ry (Rosicrucian Brotherhood AMORC-Finland). It operates as a Grand Lodge, although it does not officially have that status yet, due to the low number of members in Finland (less than 500).

It is difficult to estimate when AMORC received its first Finnish members, but it has been operating in Finland at least from the 1950s onward. The estimated number of members in AMORC-Finland today is about 200 . 
The second branch of the International Rosicrucian Order with activities in Finland is Lectorium Rosicrucianum ry or the International School of the Golden Rosycross, a society established in the Netherlands in 1932. The society began its activities in Finland in 1995 and it was officially registered in 1997. The number of Finnish members is very low at 21. A third branch of the International Rosicrucian Order operating in Finland is the Rosicrucian Order, or the Rose Cross Order, originally established in 1988. It has its headquarters in the Canary Islands. The Rose Cross Order was registered in Finland in 2002, but it does not seem to have any officially organized activities in Finland at the moment.

The Rosicrucian tradition particular to Finland is represented by The Finnish Rosicrucian Society (Ruusu-Risti, Rosy-Cross). The Society was established by Pekka Ervast (1875-1934), the former Secretary General of the Finnish Theosophical Society, in 1920. He left the Theosophical Society and established this Rosicrucian order to promote an occult interpretation of Jesus and his role as a spiritual guide for the whole of humanity. Many of the members of the Finnish Theosophical Society, and even some local lodges as a whole, joined this new society so that membership amounted to about 200 in the very beginning. Today the society has about 270 members.

\section{The Finnish Rosicrucian Society (Ruusu-Risti ry)}

The Finnish Rosicrucian Society, Ruusu-Risti (Rosy-Cross), was born due to a schism within the Finnish Theosophical Society. Its founder, Pekka Ervast did not accept Krishnamurti's authority as spiritual teacher and he also objected to the political activities of the Theosophical Society. Indeed, it defines itself as representing the original and theosophical inheritance of Helena Blavatsky. At the same time, Ervast had a strong experience of the spiritual presence of Christ in his life. He also sympathized with the ideas and worldview of the famous Russian author Leo Tolstoy. These took this Rosicrucian version of theosophy closer to Christianity and also to the international Rosicrucian orders.

The Finnish national epic Kalevala as a manifestation of the Finnish folk spirituality also plays an important role in the Finnish Rosicrucian Society.

Inside and in the core of the society there is the Inner School, which was organized and established by Pekka Ervast on the basis of CoFreemasonry. The Inner School is organized into three different stages. In order to be accepted into the Inner School, one must be a member of 
this Rosicrucian order and participate in an initiation ceremony organized every year at Easter. After this the applicant can ask the master of the Inner School to be accepted into the brotherhood.

Despite the early arrival of modern Rosicrucian orders to Finland and the development of an independent Finnish Rosicrucian tradition, interest in this movement has remained marginal. The initial success of the Finnish Rosicrucian society can be explained by a late burst of Romantic nationalism in Finland in the early decades of the twentieth century. This is mirrored in the way in which Pekka Ervast combined Christianity, theosophy and Finnish folk-traditions in his thought and writings. When the nationalistic movement lost its influence in the Finnish society and cultural environment, ideological movements and societies built on that-like Ruusu-Risti-soon became marginalized (Sjöblom \& Sohlberg 2007).

\section{The Order of International Co-Freemasonry Le Droit Humain Finnish Federation (Kansainvälinen Yhteis-Vapaamuurarijärjestö Le Droit Humain Suomen Liitto ry)}

Co-Freemasonry came to Finland from Denmark. The first lodge was founded in 1920 by initiation of 20 persons. The aforementioned $\mathrm{Mr}$ Ervast was the leader of this organization. Practically all members were also active in the Theosophical Society, so initially the theosophical impact was strong. In the late 1920s Ervast wrote an initiation grade that was based on Kalevala mythology, the Kalevala rite. The International Headquarters accepted this rite for use. Co-Freemasonry grew rapidly and for this reason the International Headquarters allowed Finland to form its own National League of Co-Freemasonry in 1925. There had, however, been problems and tensions due to Mr Ervast's leadership and finally the International Headquarters expelled both Mr Ervast and his main opponent.

Compared to the movement's early days in Finland, today just a minority of lodges are inclined to theosophy. The total number of members is about 200 (www.uskonnot.fi-Kansainvälinen Yhteis-Vapaamuurarijärjestö Le Droit Humain - Suomen Liitto ry). 


\section{Neopaganism}

Neopaganism arrived in Finland in the late 1970s through the Fellowship of Isis that promotes the Goddess spirituality. During the 1980s and early 1990s, the neopagan scene did not succeed in attracting many people (Hjelm \& Sohlberg 2004: 9-10).

However, interest in neopaganism and different forms of ritual magic has re-emerged again since the mid 1990s. Lehto - Luonnonuskontojen yhdistys ry (Lehto - The Association of Nature Religions) was founded in 1998. It is an umbrella organization for people who practice some form of nature religion. Most of the members of Lehto are Wiccans. Lehto has about 90 members (www.uskonnot.fi-Lehto - luonnonuskontojen yhdistys ry). The group called Wicca ry was founded in 2000. It is loose network for traditionalist Wiccans (i.e. Gardnerians and Alexandrians) (www.uskonnot.fi-Wicca ry).

Pakanaverkko ry (The Finnish Pagan Network) was founded in 1999 in Turku. It is important to notice that compared to Lehto, Pakanaverkko also allows Satanists to be members of their organization. Pakanaverkko is also an umbrella organization including people from different esoteric and occult traditions: ritual magic, chaos magic, different forms of paganism from Asatru to shamanism and satanism. Pakanaverkko has about 130 members. Both societies have local groups for casual meetings and discussions. These societies have also organized some national events. The Neopagan organizations have been active in their relationships with the media. Even major newspapers have published articles about neopaganism and there have also been some programs on the radio and TV about it. It is interesting to find that neopaganism, as marginal as it is, has received quite a lot of media attention (www.uskonnot. fi-Pakanaverkko ry).

Pakanatieto ry (The Pagan Information Association) was founded in 2004. It consists of only the board members and its main task is to publish information on the association's website (www.uskonnot.fiPakanatieto ry).

Most Finnish pagans are orientated into different Wiccan traditions and most Wiccans identify themselves as eclectics, combining elements from different sources. Besides them, there are a few Gardnerian and Alexandrian Wiccans too. Most pagans seem to be solitary practitioners and to my knowledge there are only few covens in Finland.

According to the survey, which I did in 2004 with my colleague about Finnish Wiccans and pagans, most informants were young people (up to 25-year-olds) and almost three quarters of them were female (Hjelm 
\& Sohlberg 2004: 10-11). The general tendency seems still to be that most Wiccans are women who have not yet reached their 30s. According to the Pakanaverkko, most of their members are people between 20-30 years of age and 60 per cent are female (2004).

Alongside this form of Western neopaganism there are a few people whose aim it is to revive and reconstruct pre-Christian Finnish paganism. But this type of paganism has not gained as much popularity as Western neopaganism.

Shamanism is often connected to the original form of Finnish preChristian religion. This view is often held among academics, too. Speaking of neoshamanism, it is interesting to find, that an American anthropologist and founder of neoshamanism, Michael Harner, organized a workshop in Finland in 1980. Then, in 1994, Shamaaniseura ry (The Shamanic Centre of Finland) was founded. The society organizes workshops and distributes information about shamanism. There are also some individuals in the field of Finnish New Age spirituality who promote shamanism. This form of shamanism is often very eclectic. Several of Carlos Castaneda's books have been translated into Finnish. There is presently one group called Kirkkaanvihreä (The Bright Green) promoting physical and spiritual practices developed by Castaneda (www.uskonnot.fi-Shamaaniseura ry, Kirkkaanvihreä ry).

The group called Wakka mysteerikoulu (The Wakka Mystery School), founded in 2004, is of purely Finnish origin. This group has created an interesting synthesis of pre-Christian Finnish religion and Western esotericism. They have their own initiation system with some Masonic influences. The group has 14 members (www.uskonnot.fi-Wakka mysteerikoulu).

It is difficult to say what really is the precise number of neopagans in many other countries and the same is true of Finland. Lehto and Pakanaverkko altogether have about 250 members. It has been estimated that the total amount would be something between 500 and 1,000 persons. To my knowledge, 1,000 is not a number likely to reflect reality, but the number of neopagans has, however, been increasing little by little (Hjelm \& Sohlberg 2004: 9-10).

\section{Other Groups of Magical Religions}

Occult groups like Temple of Set and Ordo Templi Orientis (O.T.O.) are small, but these groups have some international contacts. Pohjan Neito Encampment - Finland is an O.T.O. organization that was launched in 
1997. Its main activity is providing basic information and some Finnish translations of Aleister Crowley's texts have been published. It also organizes first grade initiations or Minerva grade initiations. Some Finnish members occasionally travel to Sweden to participate in the Gnostic mass. There are about 25 members at the moment in the Finnish O.T.O. Thelema Publications has just recently published Crowley's Book of Law in Finnish (www.uskonnot.fi-Ordo Templi Orientis - Pohjan Neito Encampment).

The first Finnish member joined the Temple of Set in 1989. The local branch-or pylon as they call it--was founded in 1991 in Helsinki. Today all the members belong to the one national pylon, Lapponia pylon. Nowadays there are about 10 members in the Temple of Set (www.uskonnot.fi-Setin temppeli).

One of the newest occult groups (consisting of just few members) is the Star of Azazel founded last year. The fraternity describes itself as a theistic satanic fraternity. It is a solely Finnish organization with no direct international background, even though there are a few small theistic satanic organizations in the world. The Star of Azazel bases its philosophy on what they call theosophical Luciferianism. Their teachings are very different from the teachings of LaVey type of satanism, which they dismiss as unworthy because of its materialistic and hedonistic principles. The group seems to be very secretive and members are expected to leave other religious organizations and political parties. It is interesting that the group emphasises the ethical formulations of the Sermon on the Mount by the famous Finnish Rosicrucian and theosophist Mr Ervast (www.uskonnot.fi-Azazelin tähti).

The distribution of occult books is, however, quite widespread. Besides mainstream and special bookstores, there are also several Finnish internet bookstores specializing in occult and esoteric literature.

The internet bookstore Athanaton sells books from a wide range of esotericism and occultism such as: ritual magic, Golden Dawn, hermetic kabbalah, Thelema, Wicca, shamanism, Asatru and satanism. Another one is Ixaxaar, which almost solely sells and also publishes books, magazines, pamphlets and music about satanism, black magic, Luciferian witchcraft, Thelema and Setian philosophy. Ixaxaar distributes, for example, pamphlets of a minor satanic organization, the Order of Nine Angles.

A new publisher is also Voimasana. It has published a Finnish edition of LaVey's Satanic Bible in 2007. Voimasana has also published a book called The Left Hand Path (Vasemman käden polku) both in Finnish and English, which is about Setian systems of beliefs and practices. 


\section{New Age Spirituality}

I will here take up a few points based on the supposed relationship between Western esotericism and New Age. As Wouter Hanegraaff, among others, has pointed out, New Age partly has its roots in Western esotericism. It can be seen as a secularised and psychological form of old esotericism. The complex field of New Age is a milieu in which ideas of esotericism are present at least to some extent, even though people seldom use the specific word 'esoteric' in New Age culture.

The concrete forms of the Finnish New Age spirituality can be seen clearly in the New Age magazines, seminars and fairs. So, it is the New Age milieu from which esoteric ideas spread to the larger audience instead of particular societies like AMORC. Themes and subjects such as messages from angelic entities, tarot symbolism, visualization techniques, use of crystals, and manipulation of universal energy are analogical to older practices in the Western esoteric and occult tradition.

The fair of alternative spirituality, Hengen ja tiedon messut (Spirit and Knowledge Fair) has been organised since 1983 (similar to the Mind, Spirit \& Body Festival in the UK). The number of attendants at the fair organized in Helsinki has varied between 3,000 and 5,000 during the last few years. In the Helsinki area another fair was started in 1996 around the famous Finnish New Age magazine Minä Olen ('I Am' magazine). Similar fairs are also held in some other towns. The total distribution or print of the three most significant magazines that represent various degrees of New Age spirituality is about 63,000: Voi hyvin ('Well Being', distribution 47,000), Minä Olen (print 11,000), and Ultra (print 5,000) (Rajatiedon yhteistyö ry, Aikakauslehtien liitto ry).

Roughly speaking, the Finnish esoteric scene can be divided into two different streams. There is the fairly new esoteric culture that includes neopaganism and ritual magic in its different forms and organizations derived from these traditions. This stream of magical religions is rather secretive and underground in its nature, consisting of a loose network rather than highly organized societies. Message boards and chat forums are places where people share their ideas and meet more or less likeminded people. People who are interested in the magical religions are mostly young adults and the majority of them are solitary practitioners.

Then there is another kind of esoteric and occult culture that mainly consists of theosophy, Rosicrucianism, spiritualism and Anthroposophy and organizations derived from these traditions. Members of these movements are often middle-age people or senior citizens. 
Most people have some kind of belief in a higher deity, but many have moved away from traditional Christian system of beliefs. Instead, these people prefer eclectic and fluid sets of beliefs, which they often describe as representing 'spirituality', not 'religion'.

To sum up, it is fair to say that diverse occult and esoteric traditions are present in the Finnish religious culture. Actually, another article would be needed, if we were to take a closer look at the New Age spirituality in Finland and on what scale the ideas of esotericism are present there. The total membership of specific esoteric and occult groups is just a few thousand. Esoteric groups are marginal, but on the whole it is fair to say that the esoteric culture in its myriad and popular forms has become more widespread than ever, although the actual membership of the societies has remained low.

\section{References}

\section{Literature}

\section{Hjelm, Titus \& Jussi Sohlberg}

2004 Jumalattaren helmassa. Wicca nuorten uskonnollisena liikkeenä. Nuorisotutkimus-lehti 2: 3-19.

\section{Ketola, Kimmo}

2003 Uusi kansanomainen uskonnollisuus. In: Kimmo Kääriäinen, Kati Niemelä \& Kimmo Ketola (eds), Moderni kirkkokansa. Suomalaisten uskonnollisuus uudella vuosituhannella; pp. 53-86. Tampere: Kirkon tutkimuskeskus. (Kirkon tutkimuskeskuksen julkaisuja, 82)

\section{Sjöblom, Tom \& Jussi Sohlberg}

2007 Modern Rosicrucianism in Finland. Unpublished article.

\section{Uskonnot Suomessa -tietokanta (The Database of Religions in Finland)} http://www.uskonnot.fi/

Teosofinen seura ry (Theosopical Society)

Vapaa katolinen kirkko Suomessa (The Liberal Catholic Church in Finland)

Kristosofinen kirjallisuusseura ry (Christosophical Literature Society)

Ihmisyyden tunnustajat (Confessors of Humanity)

Alice A. Bailey -seura ry (Alice A. Bailey Society)

Antroposofinen liitto ry (The Anthroposophical League)

Kristiyhteisö Suomessa (The Christi Society in Finland)

Parapsykologinen tutkimusseura ry (Parapsychological Research Society)

Suomen spiritualistinen seura ry (Spiritualist Association in Finland)

Via ry. (The Via Association)

Ruusu-Ristin Veljeskunta - AMORC Suomi ry (Rosicrucian Brotherhood

AMORC-Finland) 


\author{
Ruusu-Risti ry (Rosy-Cross) \\ Lectorium Rosicrucianum ry \\ Kansainvälinen Yhteis-Vapaamuurarijärjestä Le Droit Humain - Suomen \\ Liitto ry (The Order of International Co-Freemasonry Le Droit Humain \\ Finnish Federation) \\ Lehto-luonnonuskontojen yhdistys ry (Lehto - The Association of Nature \\ Religions) \\ Wicca ry. \\ Pakanaverkko ry (The Finnish Pagan Network) \\ Pakanatieto ry (The Pagan Information Association) \\ Shamaaniseura ry (The Shamanic Centre of Finland) \\ Kirkkaanvihreä ry (The Bright Green) \\ Wakka mysteerikoulu (The Wakka Mystery School) \\ Pohjan Neito - O.T.O. Camp Finland \\ Setin temppeli (The Temple of Set) \\ Azazelin tähti (The Star of Azazel)
}

\title{
Other Internet Sources
}

Suomen Ufotutkijat ry (The Finnish UFO Research Association): Ufotutkimuksen vaiheita Suomessa 30-luvulta 80-luvulle. http: / / www.suomenufotutkijat.fi/ tutkimushistoriaa.htm (accessed 30 December 2007).

Aikakauslehtien liitto (Federation of Magazine Publishers): Minä Olen, Ultra, Voi hyvin.http: / / www.aikakaus.fi / default.asp?docId=14107\&lista=luokat\& luokka=a\&vuosi=2008\&lang=fin\&info (accessed 30 December 2007).

Rajatiedon yhteistyö ry (Co-operation Network for the Paranormal and Psychic): http://www.rajatieto.fi/fi/hengen_ja_tiedon_messut/helsinki (accessed 30 December 2007).

\section{Publishers \& Internet Bookstores}

Thelema Julkaisut Oy: http:/ / www.thelema.fi/ (accessed 30 December 2007). Athanaton: www.athanaton.fi/ (accessed 30 December 2007). Ixaxaar: http: / / www.ixaxaar.com/ (accessed 30 December 2007).

Voimasana: http: / / www.voimasana.fi/ (accessed 30 December 2007). 